\title{
Study on the Interaction between Cadmium Sulphide Nanoparticles and Proteins by Resonance Rayleigh Scattering Spectra
}

\author{
Weiwei Zhu, ${ }^{1}$ Qi Wang, ${ }^{2}$ and Dan $\mathrm{Su}^{3}$ \\ ${ }^{1}$ Department of Chemistry and Life Science, Hechi University, Yizhou, Guangxi 546300, China \\ ${ }^{2}$ Research Center for Analysis and Measurement, Kunming University of Science and Technology, Kunming 650093, China \\ ${ }^{3}$ Kunming Dihon Pharmaceutical Co., Ltd., Kunming 650000, China \\ Correspondence should be addressed to Qi Wang; kmuac@163.com
}

Received 29 June 2013; Revised 31 October 2013; Accepted 14 November 2013

Academic Editor: Roberto Comparelli

Copyright ( 2013 Weiwei Zhu et al. This is an open access article distributed under the Creative Commons Attribution License, which permits unrestricted use, distribution, and reproduction in any medium, provided the original work is properly cited.

\begin{abstract}
The interaction of cadmium sulphide nanoparticles $\left[(\mathrm{CdS})_{n}\right]$ with proteins has been studied by resonance Rayleigh scattering spectra (RRS). Below the isoelectric point, proteins such as bovine serum albumin (BSA), human serum albumin (HSA), lysozyme (Lys), hemoglobin (HGB), and ovalbumin (OVA) can bind with (CdS) ${ }_{n}$ to form macromolecules by virtue of electrostatic attraction and hydrophobic force. It can result in the enhancement of resonance Rayleigh scattering spectra (RRS) intensity. Their maximum scattering peaks were $280 \mathrm{~nm}$, and there was a smaller peak at $370 \mathrm{~nm}$. The scattering enhancement $\left(\Delta I_{\mathrm{RRS}}\right)$ is directly proportional to the concentration of proteins. A new RRS method for the determination of trace proteins using uncapped (CdS) nanoparticles probe has been developed. The detection limits are $19.6 \mathrm{ng} / \mathrm{mL}$ for HSA, $16.7 \mathrm{ng} / \mathrm{mL}$ for BSA, $18.5 \mathrm{ng} / \mathrm{mL}$ for OVA, $80.2 \mathrm{ng} / \mathrm{mL}$ for HGB, and $67.4 \mathrm{ng} / \mathrm{mL}$ for Lys, separately. In this work, the optimum condition of reaction, the effect of foreign, and the analytical application had been investigated.
\end{abstract}

\section{Introduction}

In recent years, nanoparticles (NPs) are gaining an intensive interest in many academic and industrial fields, especially their use in detection of proteins and DNA $[1,2]$. This is not only due to the unique optical properties of these NPs, such as size-dependent tunable emission wavelength and exceptional photochemical stability but also due to their dimensional similarities with biological molecules [3]. Recently, The interaction of cadmium sulphide nanoparticles $\left[(\mathrm{CdS})_{n}\right]$ with protein has been studied using various methods, such as UVVis spectroscopy [4], fluorescence spectroscopy [5], Raman spectroscopy [6], dynamic light scattering [6], scanning electron microscopy, and X-ray diffraction [7]. However, Asja Jhonsi et al. discovered that the interaction between uncapped CdS and BSA was very weak [3]. So, a lot of studies have focused on capped CdS nanoparticles by using various capping agents, such as thioglycerol [8], L-cysteine [9], acrylic acid [10], and starch [11]. And the results show that the most sensitive quantitation of protein is generally based on their fluorescence enhancement effect on organic dyes. However, the organic fluorophores often suffer from photobleaching, low signal intensities, and random on/off light emission $[12,13]$. So, further studies of interaction between uncapped CdS nanoparticles and protein are significant for some new methods.

We have found that the chemically unmodified gold nanoparticles can be used as some spectral probes by the method of resonance Rayleigh scattering intensity (RRS) [14]. The structure of gold nanoparticles prepared by the sodium citrate reduction method is composed of a metal inner core $\left(\mathrm{Au}^{0}\right)$ and the surface of $\mathrm{Au}^{+}$with positive charges. Because of the electrostatic force, hydrogen bond, and hydrophobic effects, self-assembly of citrate anions will occur on the surface of gold nanoparticles to form supermolecular compounds with negative charges which can further react with some proteins, the amino acid residues of which are positively charged. The large volume aggregates cause the 
change of the absorption spectra and a red shift of the maximum absorption wavelength, at the same time the obvious enhancement of RRS.

At present, our study shows that, in hexametaphosphate medium, the surface of CdS nanoparticle has positive charges, on which the hexametaphosphate anion is self-assembled by electrostatic attraction to form $\left\{(\mathrm{CdS})_{n}\left[\left(\mathrm{PO}_{3}\right)_{6}\right]_{m}\right\}^{x-}$ complex. The anionic complex can bind further with protein cation because the amino acid residues of BSA, HSA, Lys, HGB, and OVA are positively charged in the optimum $\mathrm{pH}$ buffer solution. The spectral features of the products form by $(\mathrm{CdS})_{n}$ and the five proteins are similar. The significant enhancement of RRS intensity and new RRS spectrum are observed. This method has high sensitivity and the detection limits are in the range of $16.7-80.2 \mathrm{ng} / \mathrm{mL}$ for different proteins. So it is suitable for the determination of trace amount of proteins.

\section{Experimental}

2.1. Apparatus and Chemicals. A Hitachi F-7500 spectrofluorophotometer (Tokyo, Japan) was used to record the RRS and measure the scattering intensities. A PHS-3C $\mathrm{pH}$ meter (Shanghai Dazhong Analytical Instrument Plant, China) was used to adjust $\mathrm{pH}$. The high resolution transmission electron microscopy (HRTEM) images were obtained with Philips (Tecnai series) transmission electron microscope operated at $300 \mathrm{keV}$. Surface charge measurements were performed with a Zeta Potential Analyzer (BECKMAN, Delsa 440SX). The crystalline phases of the samples were investigated by Xray powder diffraction (XRD) with a Rigaku D/max 2200 Diffractometer with $\mathrm{Cu} \mathrm{K} \alpha(\lambda=1.542 \AA)$ radiation operated at $36 \mathrm{kV}$ and $30 \mathrm{~mA}$.

Cadmium Chloride $\left(\mathrm{CdCl}_{2} \cdot 9 \mathrm{H}_{2} \mathrm{O}\right)$ solution was $0.1 \mathrm{~mol} / \mathrm{L}$. Thioacetamide $\left(\mathrm{CH}_{3} \mathrm{CSNH}_{2}\right.$, TAA) solution was $0.1 \mathrm{~mol} / \mathrm{L}$. Sodium hexametaphosphate solution $\left[\mathrm{Na}_{6}\left(\mathrm{PO}_{3}\right)_{6}\right]$ was $0.1 \mathrm{~mol} / \mathrm{L}$.

Protein solutions: all the working solutions of human serum albumin (HSA, Sino-American Biotechnology Company), bovine serum albumin (BSA, Sino-American Biotechnology Company), lysozyme (Lys, Sino-American Biotechnology Company), hemoglobin (HGB, Sino-American Biotechnology Company), and ovalbumin (OVA, Sino-American Biotechnology Company) were $50.0 \mu \mathrm{g} / \mathrm{mL}$.

Britton-Robinson (BR) buffer solution: different $\mathrm{pH}$ buffer solutions were prepared by mixing $0.2 \mathrm{~mol} / \mathrm{L} \mathrm{NaOH}$ and the mixture of $0.04 \mathrm{~mol} / \mathrm{L} \mathrm{H}_{3} \mathrm{PO}_{4}, \mathrm{H}_{3} \mathrm{BO}_{3}$, and $\mathrm{CH}_{3} \mathrm{COOH}$ in a suitable proportion.

All reagents were analytical reagent grade and doubly distilled water was used.

\subsection{Preparation of Cadmium Sulphide Nanoparticles $\left[(C d S)_{n}\right]$.} Cadmium sulphide nanoparticles $\left[(\mathrm{CdS})_{n}\right]$ were prepared as follows. $1.0 \mathrm{~mL}$ of $0.1 \mathrm{~mol} / \mathrm{L} \mathrm{CdCl}_{2}$ and about $80 \mathrm{~mL}$ water were added in a $150 \mathrm{~mL}$ beaker. $10.0 \mathrm{~mL}$ of $0.01 \mathrm{~mol} / \mathrm{L}$ $\mathrm{CH}_{3} \mathrm{CSNH}_{2}$ was added and then $1.5 \mathrm{~mL}$ of $0.1 \mathrm{~mol} / \mathrm{L}$ sodium hexametaphosphate was added into the solution as a stabilizer. With a strong magnetic stirring, $0.10 \mathrm{~mol} / \mathrm{L} \mathrm{NaOH}$ solution was added in order to adjust $\mathrm{pH}$ to 10.4. After setting the solution aside for $30 \mathrm{~min}$, the solution was transferred into a $100 \mathrm{~mL}$ calibrated flask and diluted to the mark with water.

2.3. Experimental Procedure. In a $10 \mathrm{~mL}$ calibrated flask, appropriate amounts of working proteins such as HSA, BSA, HGB, Lys and OVA, (CdS) nanoparticles, and buffer solution were added in turn, mixed and finally diluted to the mark with doubly distilled water, mixed. The RRS intensity of the solutions was recorded by synchronous scanning at $\lambda_{\mathrm{ex}}=$ $\lambda_{\mathrm{em}}$. The RRS intensity of the binding product $\left(I_{\mathrm{RRS}}\right)$ and the reagent blank $\left(I_{\mathrm{RRS}}^{0}\right)$ were measured at the maximum wavelength, and $\Delta I_{\mathrm{RRS}}=I_{\mathrm{RRS}}-I_{\mathrm{RRS}}^{0}$.

\section{Results and Discussion}

3.1. X-Ray Powder Diffraction of $(C d S)_{n}$ Nanoparticles. To confirm the formation of $(\mathrm{CdS})_{n}$ nanoparticles, the phase purity and crystallinity of the sample were monitored by Xray powder diffraction (Figure 1). As shown in the figure, the sample shows the identical diffraction patterns. No significant difference can be observed. In addition, all the peaks are a little wide. According to the JCPDF standard card no. 0750581, the patterns can be indexed to hawleyite structure. The average grain size was calculated from the 111 peaks $\left(26.5^{\circ}\right)$ using the Scherrer equation. The average CdS size is about $4.6 \mathrm{~nm}$.

3.2. Resonance Rayleigh Scattering Spectra. The RRS spectra of $(\mathrm{CdS})_{n}$ protein systems are shown in Figure 2 . We can see from it that under the experimental condition: (1) the RRS intensity of $(\mathrm{CdS})_{n}$ and the maximum RRS peaks are located at $275 \mathrm{~nm}$; however, proteins themselves have weak RRS; (2) when $(\mathrm{CdS})_{n}$ interact with proteins, the RRS intensities are greatly enhanced, the maximum RRS peaks are located at $280 \mathrm{~nm}$, and new weak shoulder peak appears at $370 \mathrm{~nm}$; (3) the order of the relative scattering intensities is BSA > HSA > OVA > Lys > HGB.

Taking HSA as an example, Figure 3 shows that the enhancement of RRS intensity for $(\mathrm{CdS})_{n}$-HSA system is coincident with an increased concentration of HSA. Hence, the RRS method can be applied to the determination of proteins.

3.3. Optimum Solution Acidity for the Reaction. Three buffer solutions such as $\mathrm{HAc}-\mathrm{NaAc}, \mathrm{BR}$, and $\mathrm{HCl}-\mathrm{NaAc}$ were used to investigate the effects of solution acidity on the RRS. The results showed that the $\mathrm{BR}$ buffer solution was the most suitable. The effects of BR buffer solution acidity on the RRS intensity of the $(\mathrm{CdS})_{n}$-HSA system are shown in Figure 4. It can be seen that the optimum $\mathrm{pH}$ range of the actions was 3.0 4.9. If $\mathrm{pH}$ was higher than 5.0, $\Delta I_{\mathrm{RRS}}$ decreased remarkably. In this work, we chose $\mathrm{pH} 3.3$ as reaction acidity, and the appropriate volume was $0.5 \mathrm{~mL}$.

3.4. Effects of the Amounts of $(C d S)_{n}$ Nanoparticles. The effects of the amounts of $(\mathrm{CdS})_{n}$ nanoparticles solution $\left(\left[(\mathrm{CdS})_{n}\right]=5.0 \times 10^{-5} \mathrm{~mol} / \mathrm{L}\right)$ on RRS of five systems were 


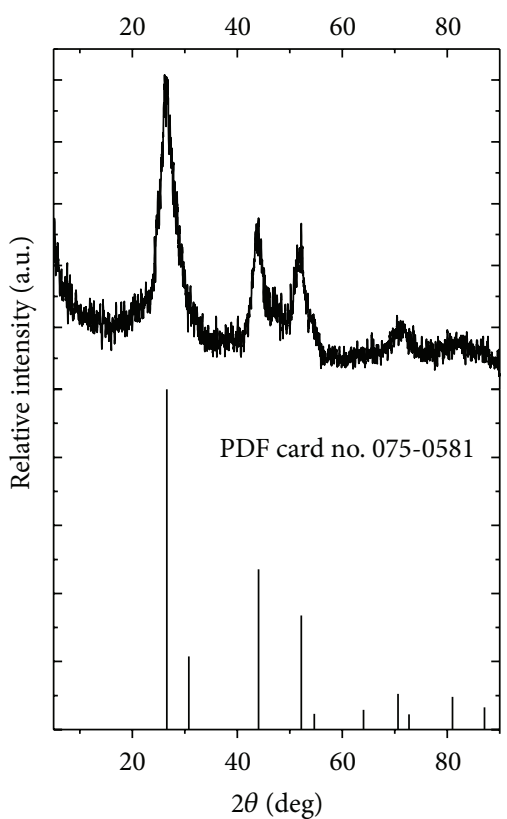

FIGURE 1: The XRD pattern of $(\mathrm{CdS})_{n}$.

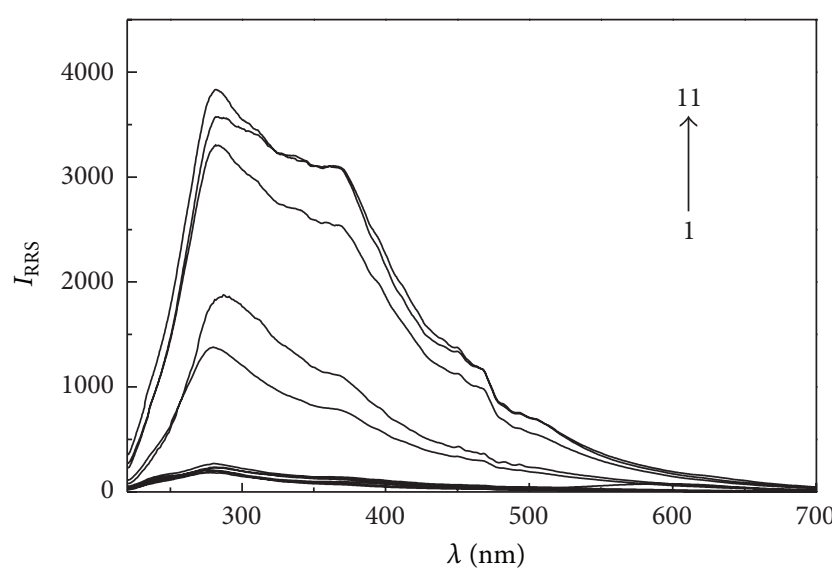

FIGURE 2: The RRS spectra of binding products of $(\mathrm{CdS})_{n}$ with proteins. 1:(CdS $)_{n}$, 2: HSA, 3: BSA, 4: OVA, 5: HGB, 6: Lys, 7: (CdS $)_{n}$-HGB, 8: (CdS $)_{n}$-Lys, 9: (CdS $)_{n}$-OVA, 10: (CdS $)_{n}$-HSA, and 11: $(\mathrm{CdS})_{n}$-BSA. Proteins concentrations: $2.5 \mu \mathrm{g} / \mathrm{mL}$; $(\mathrm{CdS})_{n}$ concentration: $6.0 \times 10^{-5} \mathrm{~mol} / \mathrm{L}$.

investigated. The results shown in Figure 5 revealed that the optimum amounts are $6.0 \times 10^{-5} \mathrm{~mol} / \mathrm{L}$ for HSA system, $6.0 \times$ $10^{-5} \mathrm{~mol} / \mathrm{L}$ for BSA system, $4.0 \times 10^{-5} \mathrm{~mol} / \mathrm{L}$ for OVA system, $5.0 \times 10^{-5} \mathrm{~mol} / \mathrm{L}$ for Lys system, and $7.0 \times 10^{-5} \mathrm{~mol} / \mathrm{L}$ for HGB system. If the $(\mathrm{CdS})_{n}$ nanoparticles concentration was lower or higher than the previous concentrations, RRS intensities became lower. So, $6.0 \times 10^{-5} \mathrm{~mol} / \mathrm{L}, 6.0 \times 10^{-5} \mathrm{~mol} / \mathrm{L}, 4.0 \times$ $10^{-5} \mathrm{~mol} / \mathrm{L}, 5.0 \times 10^{-5} \mathrm{~mol} / \mathrm{L}$, and $7.0 \times 10^{-5} \mathrm{~mol} / \mathrm{L}$ were chosen, respectively, as suitable HAS, BSA, OVA, Lys, and HGB concentrations, respectively.

3.5. Reaction Speed and the Stability. Under the optimum experimental conditions, the formation velocity and the time

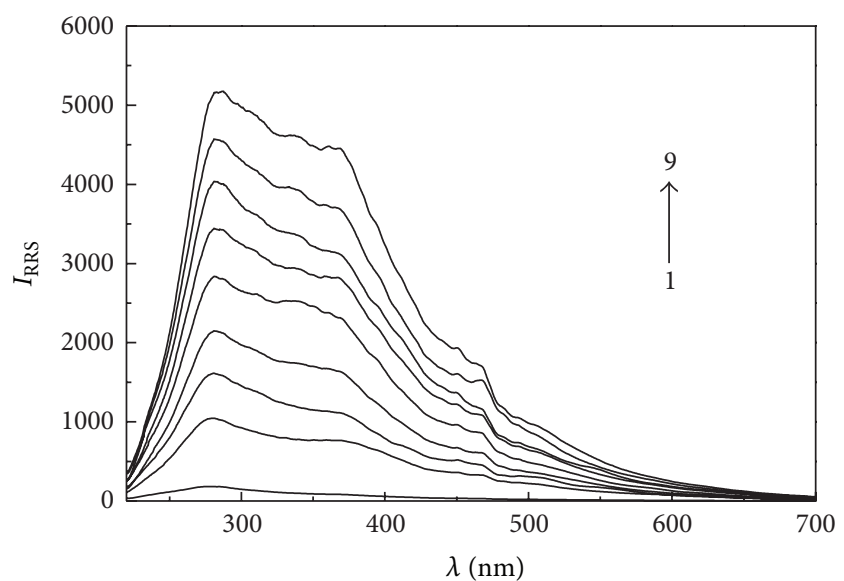

FIgURE 3: The RRS spectra of (CdS $)_{n}$-HAS. and 1: $(\mathrm{CdS})_{n}$ and 2 9: HAS- $(\mathrm{CdS})_{n}$ (HSA concentration: $0.5,1.0,1.5,2.0,2.5,3.0,3.5$, and $4.0 \mu \mathrm{g} / \mathrm{mL})$; $(\mathrm{CdS})_{n}$ concentration: $6.0 \times 10^{-5} \mathrm{~mol} / \mathrm{L}$.

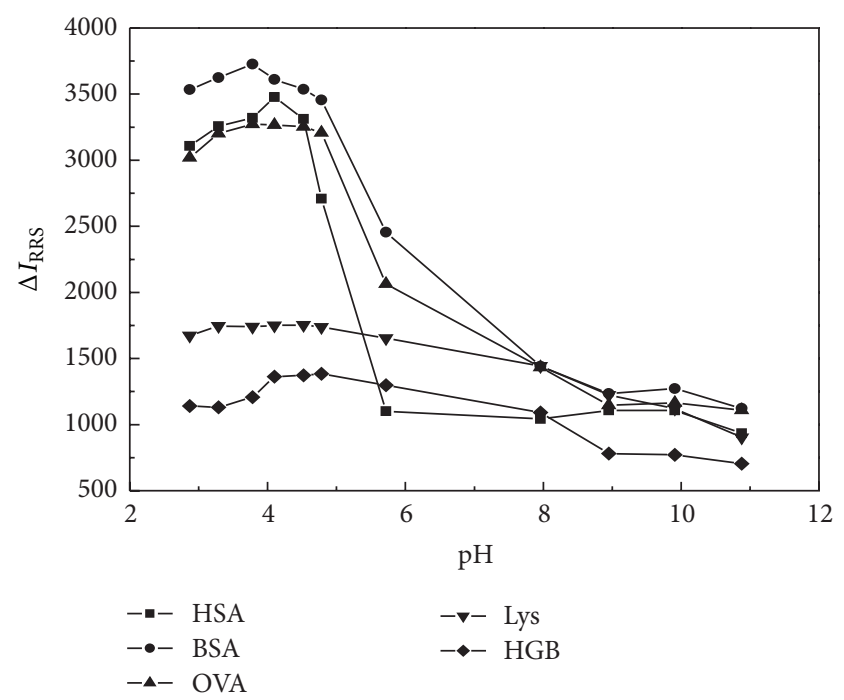

FIGURE 4: Effect of acidity on $\Delta I_{\text {RRS }}$. HSA concentrations: $2.5 \mu \mathrm{g} / \mathrm{mL}$; CdS concentration: $6.0 \times 10^{-5} \mathrm{~mol} / \mathrm{L}$.

of stability were studied. The reactions completed in about 10 minutes at room temperature and the $\Delta I_{\mathrm{RRS}}$ was kept constant for 2 hours. All results showed that the reactive products had good stability.

3.6. Sensitivity of Method. Under the optimum conditions, when $(\mathrm{CdS})_{n}$ interacted with the proteins of different concentrations to form complex product, the RRS intensity at the maximum wavelength was measured. The calibration graphs of RRS intensity versus the concentrations of proteins were constructed. The linear ranges, relevant coefficients, and the detecting limits are listed in Table 1 and compared with other RRS methods (Table 2).

3.7. Binding $(C d S)_{n}$ Nanoparticles with Proteins. It is a general thinking that the $(\mathrm{CdS})_{n}$ nanoparticles prepared 
TABLE 1: Linear ranges, correlation coefficient, and detection limits.

\begin{tabular}{lccccc}
\hline $\begin{array}{l}\text { Detected } \\
\text { protein }\end{array}$ & $\begin{array}{c}\text { Measurement } \\
\text { wavelength } /(\mathrm{nm})\end{array}$ & $\begin{array}{c}\text { Linear regression } \\
\text { equation } /(c=\mu \mathrm{g} / \mathrm{mL})\end{array}$ & $\begin{array}{c}\text { Correlation } \\
\text { coefficient }\end{array}$ & $\begin{array}{c}\text { Linear } \\
\text { ranges } /(\mu \mathrm{g} / \mathrm{mL})\end{array}$ & $\begin{array}{c}\text { Detection } \\
\text { limits } /(\mathrm{ng} / \mathrm{mL})\end{array}$ \\
\hline HSA & 282 & $\Delta I=253.6+1186.3 c$ & 0.9997 & $0.065 \sim 5.0$ & 19.6 \\
BSA & 283 & $\Delta I=315.4+1393.6 c$ & 0.9963 & $0.056 \sim 4.5$ & 16.7 \\
OVA & 282 & $\Delta I=-153.1+1255.6 c$ & 0.9985 & $0.062 \sim 5.0$ & 18.5 \\
HGB & 280 & $\Delta I=20.5+290.1 c$ & 0.9974 & $0.267 \sim 4.0$ & 80.2 \\
Lys & 287 & $\Delta I=117.4+344.8 c$ & 0.9968 & $0.223 \sim 4.0$ & 67.4 \\
\hline
\end{tabular}

TABLE 2: Comparison of sensitivities of some RRS methods for the determination of HSA.

\begin{tabular}{|c|c|c|c|c|}
\hline Reagents & $\begin{array}{c}\text { Determination } \\
\text { wavelength }(\mathrm{nm})\end{array}$ & $\begin{array}{c}\text { Linear ranges } \\
(\mu \mathrm{g} / \mathrm{mL})\end{array}$ & $\begin{array}{l}\text { Detection limits } \\
(\mathrm{ng} / \mathrm{mL})\end{array}$ & Reference \\
\hline Alizarin Red S & 360 & $0.2 \sim 15.5$ & 9.51 & {$[15]$} \\
\hline PSbMoB & 470 & $0 \sim 4.0$ & 12.5 & [16] \\
\hline Chrome azurol S-Al ${ }^{3+}$ & 410 & $2.5 \sim 60$ & 89.6 & {$[17]$} \\
\hline Chlorophosphonazo III (CPAIII) & 417 & $0 \sim 4.9$ & 70.5 & {$[18]$} \\
\hline Chrome azurol S (CAS) & 370 & $0 \sim 1.0$ & 20.0 & {$[19]$} \\
\hline Gold nanoparticles & 303 & $0.0013 \sim 0.45$ & 0.38 & {$[14]$} \\
\hline CdS particles & 280 & $0.065 \sim 4.5$ & 19.6 & This work \\
\hline
\end{tabular}

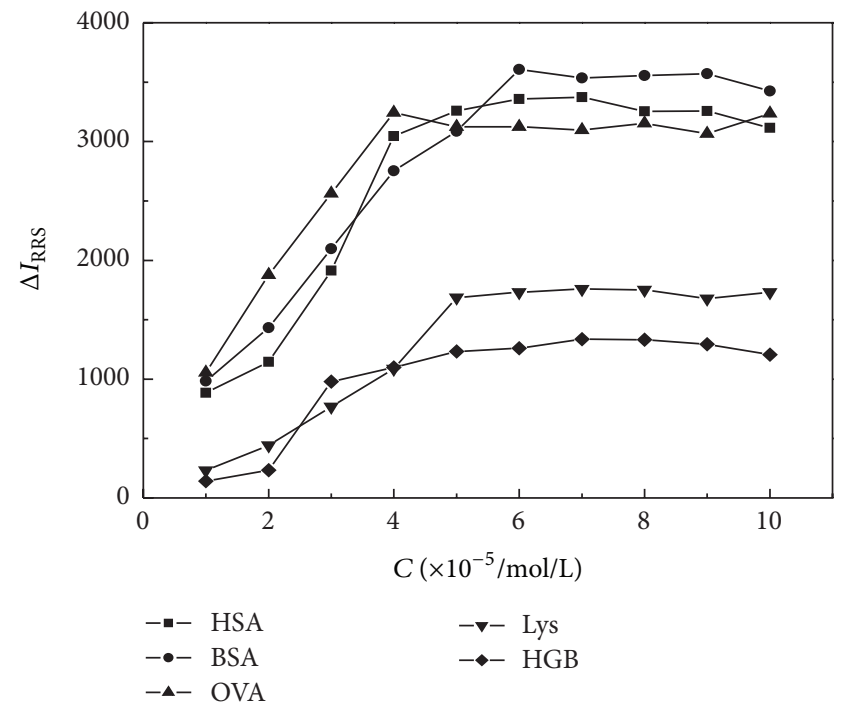

FIGURE 5: Effect of the concentration of CdS nanoparticles. HSA concentrations: $2.5 \mu \mathrm{g} / \mathrm{mL}$; $\mathrm{pH} 3.3$.

by $\mathrm{CdCl}_{2}$ and TAA with the stabilizer of sodium hexametaphosphate $\left[\mathrm{Na}_{6}\left(\mathrm{PO}_{3}\right)_{6}\right]$ are composed of $\mathrm{CdS}$ nucleus and $\mathrm{Cd}^{2+}$ crust. It makes the surface of nanoparticles positively charged. There are large amounts of $\left(\mathrm{PO}_{3}\right)_{6}{ }^{6-}$ which can selfassemble on the surface of $(\mathrm{CdS})_{n}$ nanoparticle by electrostatic attraction. It forms the supermolecule compound of $\left\{(\mathrm{CdS})_{n}\left[\left(\mathrm{PO}_{3}\right)_{6}\right]_{m}\right\}^{x-}$ with negative charges. Simultaneously, in this work, the selected optimum $\mathrm{pH}$ is below the isoelectric points of proteins (PI). In this case, $\alpha-\mathrm{COOH}$ and $-\mathrm{COOH}$ of side chain of amino acid residues in peptide chain do not dissociate, while protonation of $\alpha-\mathrm{NH}_{2}$ and $\varepsilon-\mathrm{NH}_{2}$ will make them become $-\mathrm{NH}_{3}{ }^{+}$; hence, proteins are positively charged macromolecules in the solution. The $(\mathrm{CdS})_{n}$ nanoparticles bind proteins through the "bridge" of $\left(\mathrm{PO}_{3}\right)_{6}{ }^{6-}$ surrounding the surface of the nanoparticles, and $\alpha-\mathrm{NH}_{3}{ }^{+}$and $\varepsilon-\mathrm{NH}_{3}{ }^{+}$of amino acid residues in peptide chain will bind $\left(\mathrm{PO}_{3}\right)_{6}{ }^{6-}$ by electrostatic force. Thus, the combined products of proteins and $(\mathrm{CdS})_{n}$ nanoparticles may be $\left\{(\mathrm{CdS})_{n}\left[\left(\mathrm{PO}_{3}\right)_{6}\right]_{m}\right\}^{x-}\left(\mathrm{P}^{\mathrm{y}+}\right)_{l}$.

In Figures 6(a), 6(b), 6(c), and 6(d), the shape of the $(\mathrm{CdS})_{n}$ nanoparticles and combined products were observed by HRTEM. It showed that (1) the $(\mathrm{CdS})_{n}$ nanoparticles were well distributed in the solution, and the mean diameters of them were $4 \mathrm{~nm}( \pm 2 \mathrm{~nm})$; (2) when HSA was added into the solution of $(\mathrm{CdS})_{n}$ nanoparticles, the mean diameters of the nanoparticles did not increase too much, but HSA molecules bound with the nanoparticles led the nanoparticles to gather. From Figure $6(\mathrm{~d})$, the gathering of two $(\mathrm{CdS})_{n}$ nanoparticles could be observed. The conclusion derived from that the lattice line of $(\mathrm{CdS})_{n}$ nanoparticle was fuzzy, which was in accordance with the result of XRD. The results of zeta potential measurement were shown in Figures $7(\mathrm{a})$, $7(\mathrm{~b})$, and $7(\mathrm{c})$. The zeta potential of $(\mathrm{CdS})_{n}$ nanoparticles and HAS was located at $-20.6 \mathrm{mV}$ and $4.1 \mathrm{mV}$, respectively. The reaction mixture exhibited two peaks in the result of zeta potential analysis and in Figure 7 (c) the two zeta potentials were $-12.9 \mathrm{mv}$ and $-36.8 \mathrm{mv}$, presumably as a result of two different charge particles in solution. This result also presents that the nanoparticles will further gather.

3.8. Effects of Binding the $(C d S)_{n}$ Nanoparticles with Proteins on RRS Spectral Characteristics. The RRS intensities of $(\mathrm{CdS})_{n}$ nanoparticles or proteins are very weak when they are independent, but when they co-exist in buffer solution, the RRS intensities are enhanced greatly. The reasons are as follows. 


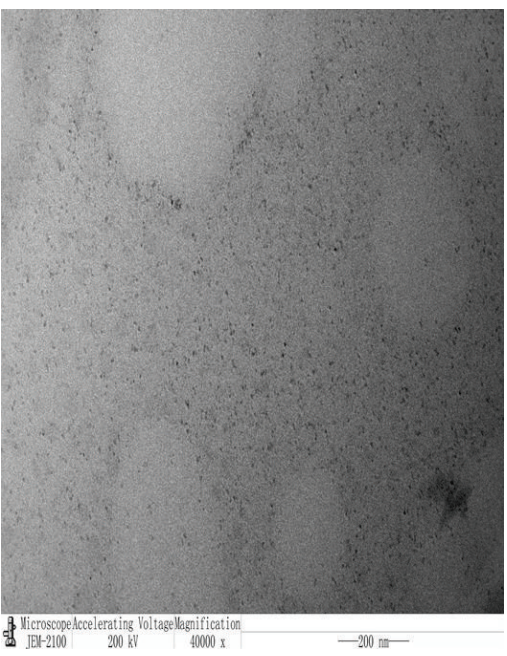

(a)

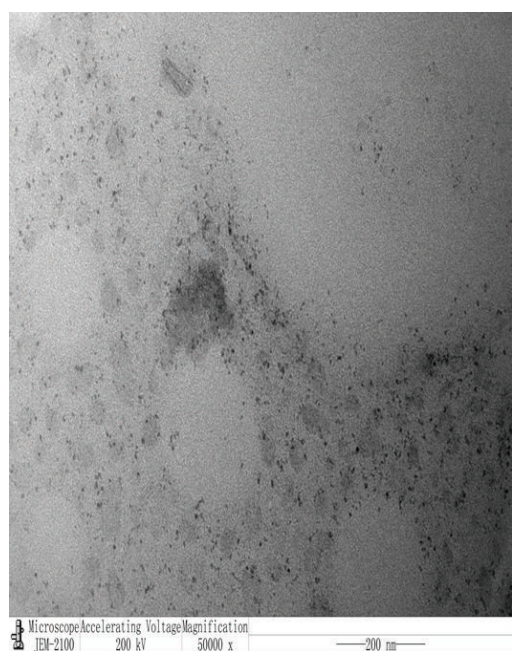

(c)

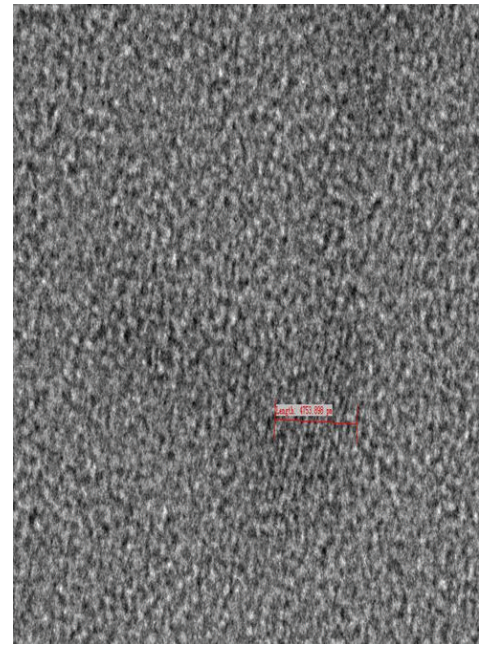

(b)

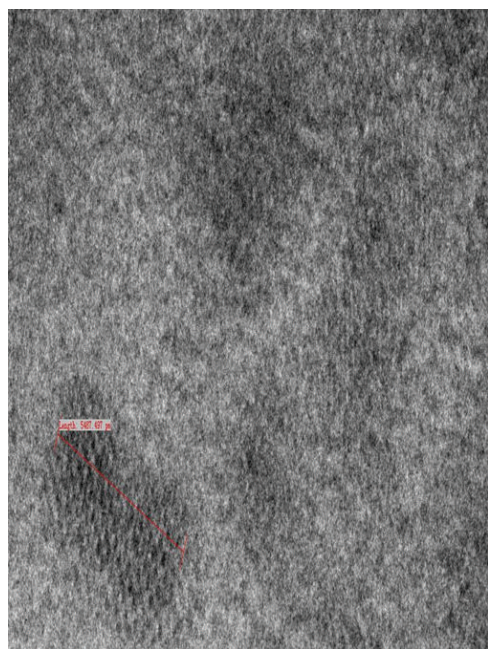

(d)

Figure 6: The HRTEM images of (CdS) ${ }_{n}$ and the binding products of HAS. $c_{(\mathrm{CdS})_{n}}=6.0 \times 10^{-4} \mathrm{~mol} / \mathrm{L} ; c_{\mathrm{HSA}} 4.0 \mathrm{~g} / \mathrm{mL} ; c_{(\mathrm{CdS})_{n}}=$ $6.0 \times 10^{-4} \mathrm{~mol} / \mathrm{L}$. (a) Typical HRTEM image of the $(\mathrm{CdS})_{n}$, (b) shows the details of the (CdS $)_{n}$. (c) Typical HRTEM image of the (CdS) ${ }_{n}$ binding with HAS. (d) shows the details of the binding product between $(\mathrm{CdS})_{n}$ and HAS.

TABLE 3: Results of the determination of proteins in synthesized samples using the RRS method.

\begin{tabular}{|c|c|c|c|c|c|}
\hline Samples & $\begin{array}{l}\text { Concentration of coexisting substances } \\
(\mu \mathrm{g} / \mathrm{mL})\end{array}$ & $\begin{array}{c}\text { Added } \\
\text { concentration of } \\
\text { HSA }(\mu \mathrm{g} / \mathrm{mL})\end{array}$ & $\begin{array}{c}\text { Determined } \\
\text { concentration of } \\
\text { HSA }(\mu \mathrm{g} / \mathrm{mL}, n=5)\end{array}$ & $\mathrm{RSD} /(\%)$ & Recovery/(\%) \\
\hline 1 & $\begin{array}{l}\text { L-Aspartic acid 5.0; threonine 5.0; glucose } \\
\text { 5.0; } \mathrm{Fe}^{3+} 2.4 ; \mathrm{K}^{+} 4.1 ; \mathrm{Cl}^{-} \text {13.5. }\end{array}$ & 2.00 & 1.87 & 2.0 & 93.5 \\
\hline 2 & $\begin{array}{l}\text { L-Histidine 5.0; glucose 5.0; carbamide } \\
5.0 ; \mathrm{Zn}^{2+} 2.3 ; \mathrm{SO}_{4}^{2-} 7.7 ; \mathrm{NH}_{4}^{+} 3.4 ; \mathrm{Cl}^{-} \text {6.6. }\end{array}$ & 1.00 & 1.12 & 1.7 & 112.0 \\
\hline 3 & $\begin{array}{l}\text { L-Tryptophan } 5.0 \text {; carbamide } 5.0 ; \mathrm{Mg}^{2+} \\
2.5 ; \mathrm{Cl}^{-} 7.5 ; \mathrm{K}^{+} 2.3 ; \mathrm{I}^{-} \text {7.7. }\end{array}$ & 0.50 & 0.54 & 0.54 & 108.0 \\
\hline
\end{tabular}

(1) Change of the conformation of the proteins and formation of macromolecules. The scattering of the proteins is weak because the proteins are stable spherical and small in the aqueous. After binding $(\mathrm{CdS})_{n}$ nanoparticles with proteins, $\alpha-\mathrm{NH}_{3}{ }^{+}$and
$\varepsilon-\mathrm{NH}_{3}{ }^{+}$of the peptide chain of proteins bind with $\left(\mathrm{PO}_{3}\right)_{6}{ }^{6-}$ by electrostatic force; the original regular and repeating secondary structures of the protein held together by peptide chain and a hydrogen bond were destroyed and the structure become extended and 


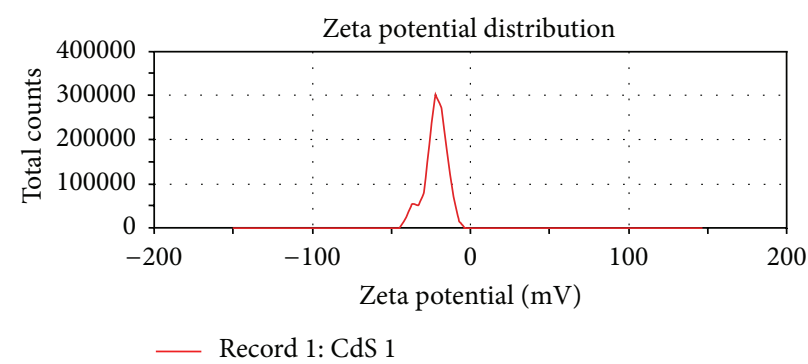

(a)

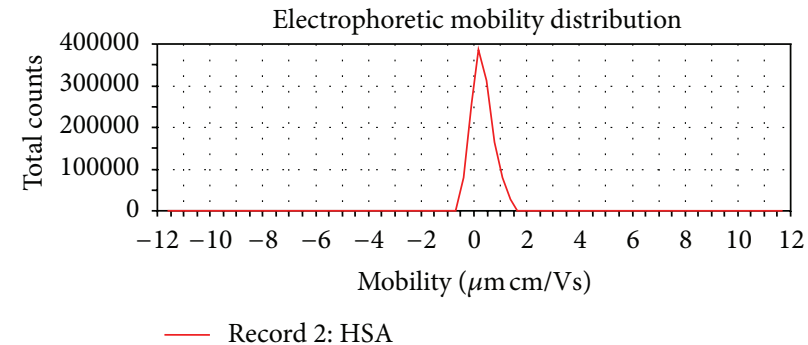

(b)

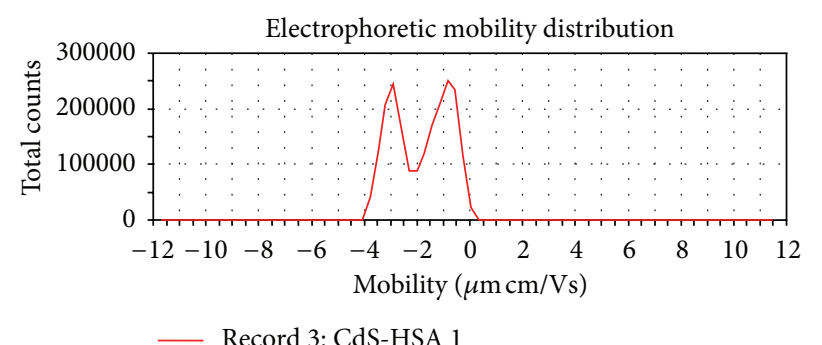

(c)

Figure 7: The zeta potential images of (CdS $)_{n}$ and the binding products of HAS. (a) The zeta potential image of (CdS) ${ }_{n}$. (b) The zeta potential image of HSA. (c) The zeta potential image of the $(\mathrm{CdS})_{n}$ binding with HAS.

TABLE 4: Results for the determination of HSA in urine and serum samples.

\begin{tabular}{|c|c|c|c|c|}
\hline \multirow{2}{*}{ Samples } & \multicolumn{2}{|l|}{ RRS method } & \multicolumn{2}{|c|}{ CBB G-250 method } \\
\hline & Determined concentration $(\mu \mathrm{g} / \mathrm{mL})$ & $\operatorname{RSD}(\%, n=5)$ & Determined concentration $(\mu \mathrm{g} / \mathrm{mL})$ & $\operatorname{RSD}(\%, n=5)$ \\
\hline$\overline{\mathrm{U} .1}$ & 4.2 & 3.7 & 4.8 & 2.3 \\
\hline $\mathrm{U} .2$ & 4.9 & 3.5 & 5.1 & 2.1 \\
\hline U.3 & 5.1 & 4.6 & 5.2 & 2.4 \\
\hline S.1 & 65.4 & 3.4 & 62.7 & 2.9 \\
\hline S.2 & 67.7 & 3.1 & 69.4 & 3.4 \\
\hline S.3 & 61.6 & 2.6 & 63.1 & 2.7 \\
\hline
\end{tabular}

loose, which is similar to the denaturation of protein. It makes the proteins aggregate to macromolecules, which enlarges the volume of compound enhancing the scattering intensity.

(2) Enhancement of hydrophobicity. After binding proteins with $c_{(\mathrm{CdS})_{n}}$ nanoparticles, most of their electric charges are neutralized, and the hydrophobic group is exposed. Therefore, the hydrophobicity of the binding products increases and a liquid-solid interface between the complex and the water may form, which produces surface enhanced scattering.

\subsection{Selectivity of RRS Method}

3.9.1. Effect of Foreign Substance. Taking HSA as an example, the effects of the metal ions, inorganic anions, some amino acids, and saccharides on the system were tested. When the HSA concentration was $2.5 \mu \mathrm{g} / \mathrm{mL}$, the existence of $\mathrm{Al}^{3+}$, $\mathrm{Mg}^{2+}, \mathrm{Mn}^{2+}, \mathrm{Fe}^{3+}$ at 10 times, $\mathrm{Cu}^{2+}, \mathrm{Ca}^{2+}$ at about 20 times, $\mathrm{Zn}^{2+}$ at 240 times, $\mathrm{K}^{+}$at 200 times, and large numbers of common amino acids, saccharides, inorganic anions, and vitamins did not interfere with the determination.

3.9.2. Determination of HSA in the Composite Samples. The proposed RRS method was applied to determine HSA in composite samples. The results were listed in Table 3. By using standard addition recovery method, the relative standard deviations (RSD) of found values were between 0.54 and $2.0 \%$, and the recoveries were between 93.5 and $112.0 \%$. There is no significant difference between added and found values.

3.9.3. Determination of HSA in the Human Urine Samples. Three copies of fresh urine samples (healthy human) were filtrated after being placed for one night. A $10 \mathrm{~mL}$ aliquot of each copy was diluted 10 times. Then a $1.0 \mathrm{~mL}$ aliquot of each solution was placed in the calibrated flask followed by $1.0 \mathrm{~mL}$ of BR buffer solution and $0.5 \mathrm{~mL}$ of $(\mathrm{CdS})_{n}$ solution. HSA was used as the standard for the determination of protein. The results are listed in Table 4 (U.1 U.3). Each serum sample was 
determined for 5 times and the relative standard deviations (RSD) were between 3.5 and $4.6 \%$.

3.9.4. Determination of HSA in the Human Serum. Three copies of fresh serum samples (healthy human) were diluted 1000 times, from $1.0 \mathrm{~mL}$ to $1.0 \mathrm{~L}$. A $0.5 \mathrm{~mL}$ aliquot of each solution was placed in the calibrated flask followed by $1.0 \mathrm{ml}$ of BR buffer solution and $0.5 \mathrm{~mL}$ of $(\mathrm{CdS})_{n}$ solution. HSA was used as the standard for the determination of protein. The results are listed in Table 4 (S.1 S.3). Each serum sample was determined for 5 times and the relative standard deviations (RSD) were between 2.6 and $3.4 \%$.

All results were satisfactory in comparison with the results determined by spectrophotometry with CBB G-250. The result shows that this method is good at determining the content of protein in complicated biological samples.

\section{Conflict of Interests}

The authors declare that they do not have any commercial or associative interest that represents a conflict of interests in connection with the work submitted.

\section{Acknowledgments}

The present work was supported by The National Natural Science Foundation of China (21003066), the Hechi University foundation (2013ZB-N001), and Hechi city foundation (1171104-010).

\section{References}

[1] M. L. Curri, A. Agostiano, G. Leo, A. Mallardi, P. Cosma, and M. Della Monica, "Development of a novel enzyme/semiconductor nanoparticles system for biosensor application," Materials Science and Engineering C, vol. 22, no. 2, pp. 449-452, 2002.

[2] S. H. Tang and Y. Q. Li, "Interaction via in situ binding of CdS nanorods onto gelatin," Journal of Colloid and Interface Science, vol. 360, no. 1, pp. 71-77, 2011.

[3] M. A. Jhonsi, A. Kathiravan, and R. Renganathan, "Spectroscopic studies on the interaction of colloidal capped CdS nanoparticles with bovine serum albumin," Colloids and Surfaces B, vol. 72, no. 2, pp. 167-172, 2009.

[4] L. Jiang, B. Q. Yang, Y. D. Ma et al., "The binding of phosphorothioate oligonucleotides to CdS nanoparticles," Chemical Physics Letters, vol. 280, no. 1-2, pp. 29-33, 2003.

[5] X. C. Shen, X. Y. Liou, L. P. Ye, H. Liang, and Z. Wang, "Spectroscopic studies on the interaction between human hemoglobin and CdS quantum dots," Journal of Colloid and Interface Science, vol. 311, no. 2, pp. 400-406, 2007.

[6] A. Datta, A. Saha, A. K. Sinha, S. N. Bhattacharyya, and S. Chatterjee, "Synthesis of CdS nanoparticles in colloidal state and its possible interaction with tyrosine," Journal of Photochemistry and Photobiology B, vol. 78, no. 1, pp. 69-75, 2005.

[7] M. J. Meziani, P. Pathak, B. A. Harruff, R. Hurezeanu, and Y. Sun, "Direct conjugation of semiconductor nanoparticles with proteins," Langmuir, vol. 21, no. 5, pp. 2008-2011, 2005.

[8] S. K. Kulkarni, A. S. Ethiraj, S. Kharrazi, D. N. Deobagkar, and D. D. Deobagkar, "Synthesis and spectral properties of DNA capped CdS nanoparticles in aqueous and non-aqueous media," Biosensors and Bioelectronics, vol. 21, no. 1, pp. 95-102, 2005.

[9] L. Ding, P. J. Zhou, S. Q. Li, G. Y. Shi, T. Zhong, and M. Wu, "Spectroscopic studies on the thermodynamics of L-cysteine capped CdSe/CdS quantum dots-BSA interactions," Journal of Fluorescence, vol. 21, no. 1, pp. 17-24, 2011.

[10] H. Q. Chen, F. Xu, S. Hong, and L. Wang, "Quantitative determination of proteins at nanogram levels by the resonance light-scattering technique with composite nanoparticles of CdS/PAA," Spectrochimica Acta A, vol. 65, no. 2, pp. 428-432, 2006.

[11] P. Rodriguez, N. Munoz-Aguirre, E. San-Martin Martinez, G. G. de la Cruzc, S. A. Tomas, and O. Z. Angel, "Synthesis and spectral properties of starch capped CdS nanoparticles in aqueous solution," Journal of Crystal Growth, vol. 310, no. 1, pp. 160-164, 2008.

[12] L. Y. Wang, Y. Y. Zhou, L. Wang, C. Zhu, Y. Li, and F. Gao, "Synchronous fluorescence determination of protein with functionalized CdS nanoparticles as a fluorescence probe," Analytica Chimica Acta, vol. 466, no. 1, pp. 87-92, 2002.

[13] A. Datta, S. Chatterjee, A. K. Sinha, S. N. Bhattacharyya, and A. Saha, "Identification of tyrosine in the presence of tryptophan using $\mathrm{Cd}^{2+}$-enriched colloidal CdS nanoparticles: a fluorescence spectroscopic study," Journal of Luminescence, vol. 121, no. 2, pp. 553-560, 2006.

[14] S. P. Liu, Z. Yang, Z. F. Liu, and L. Kong, "Resonance Rayleighscattering method for the determination of proteins with gold nanoparticle probe," Analytical Biochemistry, vol. 353, no. 1, pp. 108-116, 2006.

[15] X. L. Hu, P. Feng, and Y. F. Li, "Interactions of pyrogallol red with proteins and the determination of proteins by resonance light scattering," Journal of Southwest China Normal University (Natural Science), vol. 23, no. 5, pp. 561-566, 1998.

[16] X. F. Long and S. P. Liu, "Resonance Rayleigh scattering method for the determination of protein with PSbMo heteropoly blue," Journal of Southwest China Normal University (Natural Science), vol. 25, no. 2, pp. 155-159, 2000.

[17] R. Yang, S. P. Liu, and C. Z. Huang, "Resonance Rayleigh scattering method for the determination of proteins with aluminum-chrome azurol S chelate," Journal of Yunnan China University(Natural Science), vol. 2, pp. 63-65, 1999.

[18] S. P. Liu, L. Fan, X. F. Long et al., "Resonance Rayleigh scattering method for the determination of proteins with chlorophosphonazo III," Journal of Southwest China Normal University (Natural Science), vol. 26, no. 3, pp. 293-296, 2001.

[19] Y. J. Wei, K. A. Li, and S. Y. Tong, "Elastic light-scattering of protein-chrome azurol S complex and its preliminary analytical application," Acta Chimica Sinica, vol. 56, no. 3, pp. 296-297, 1998. 

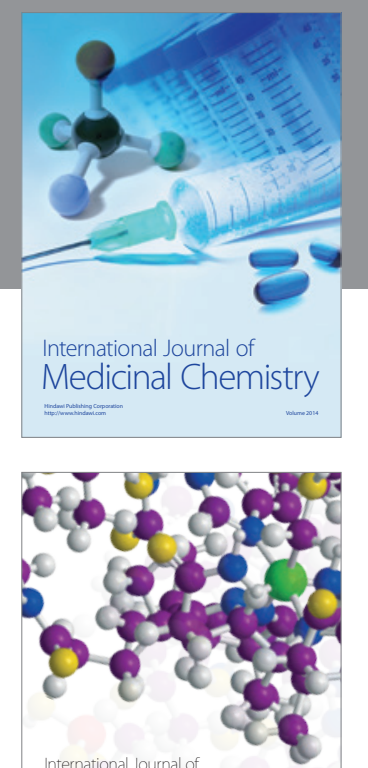

\section{Carbohydrate} Chemistry

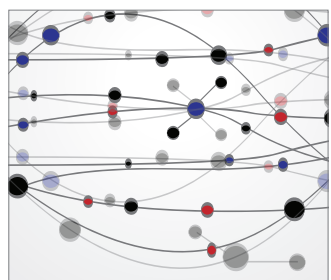

The Scientific World Journal
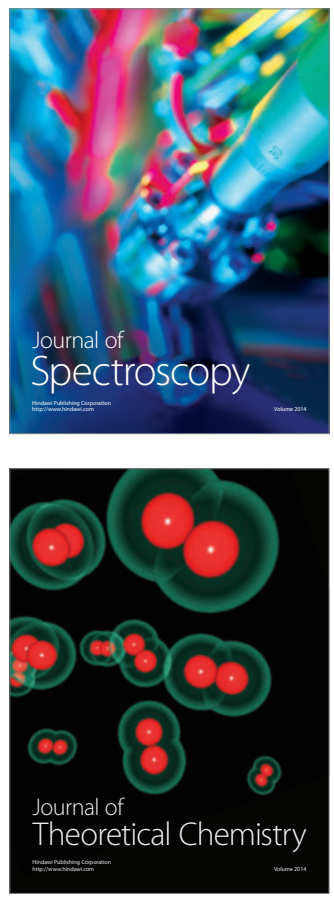
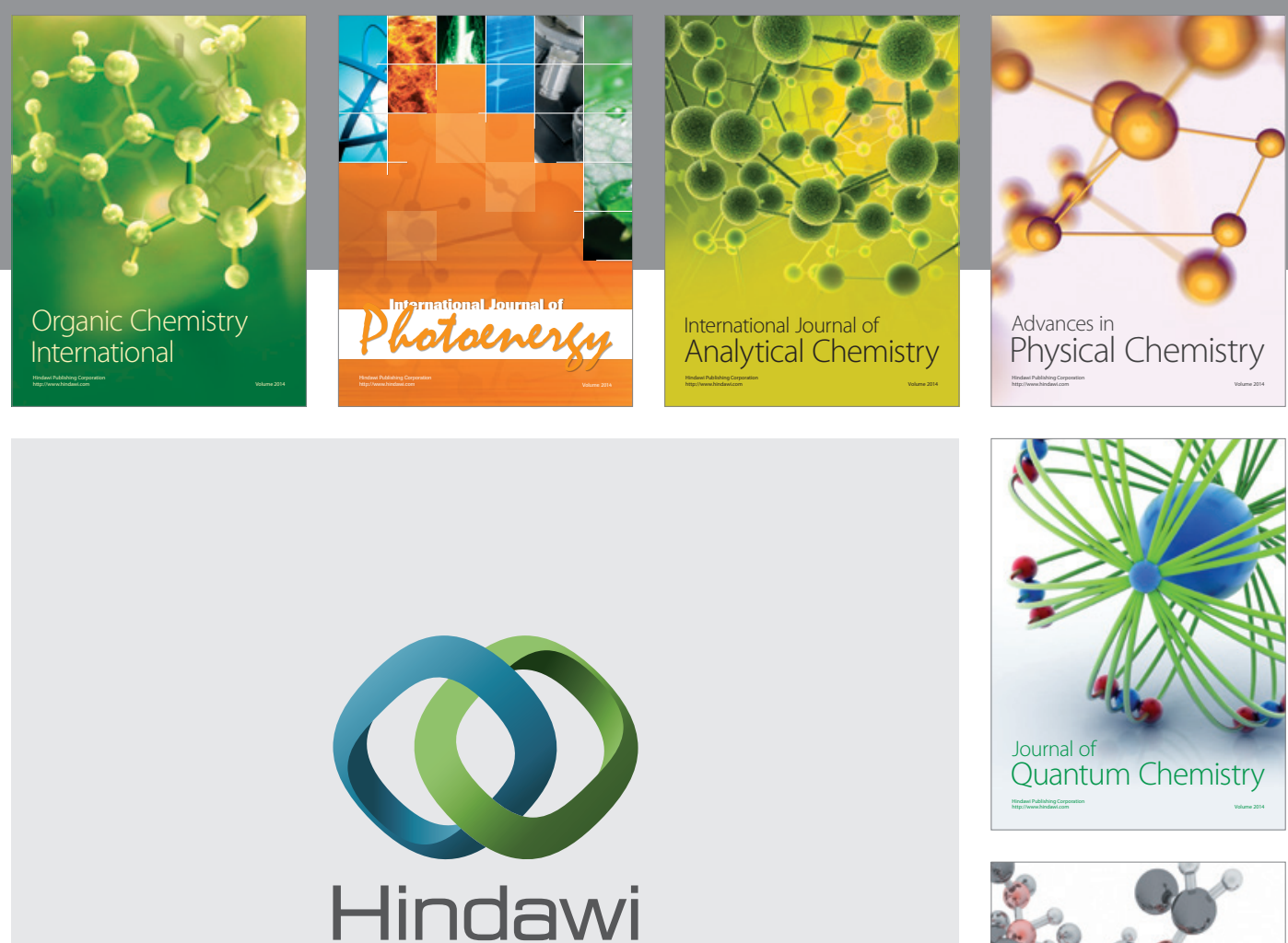

Submit your manuscripts at

http://www.hindawi.com

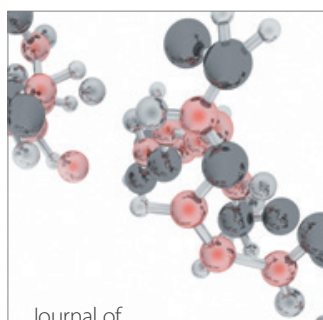

Analytical Methods

in Chemistry

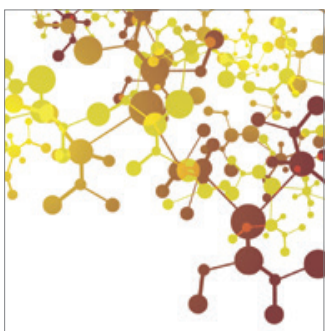

Journal of

Applied Chemistry

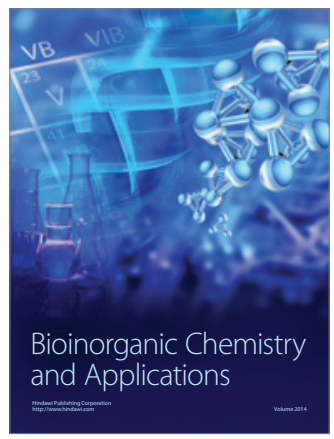

Inorganic Chemistry
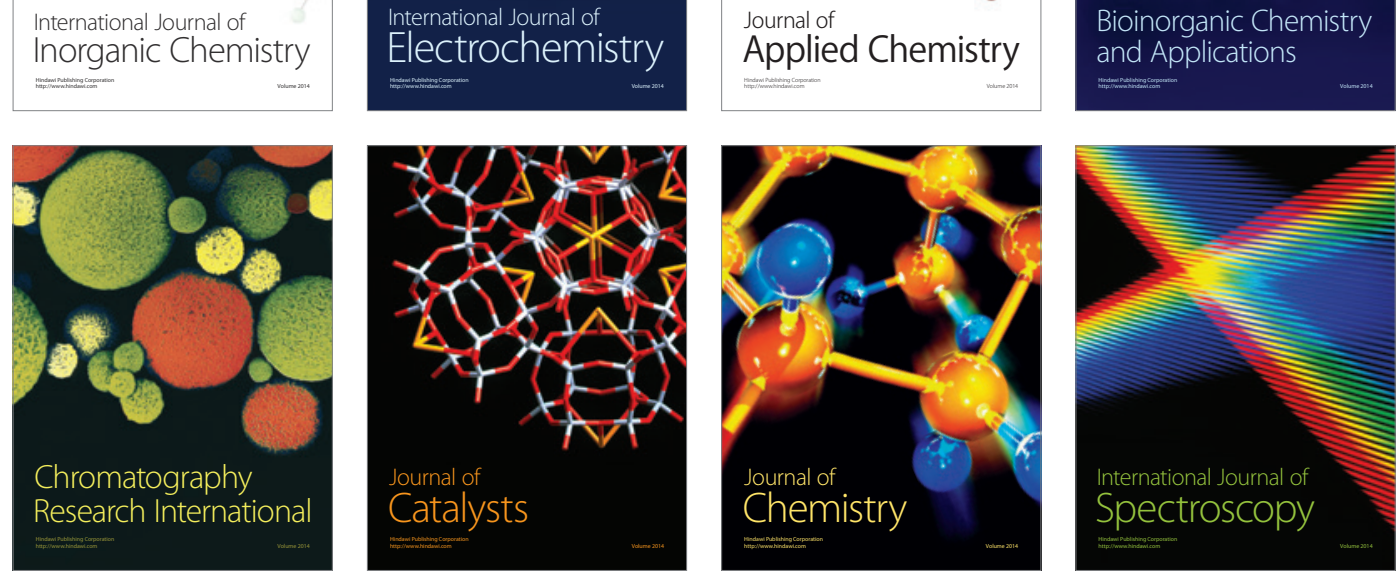